\title{
Liberation of Tin from a Tinplate Cans by Trimethylamine Oxide
}

\author{
Takeshi TAGUCH*
}

(Received May 20, 1975)

\begin{abstract}
To clarify the internal corrosion mechanism in food cans, the effect of trimethylamine oxide (TMAO) on the liberation of tin from tinplate was examined. In the range of $\mathrm{pH}$ 2.8-8.0, tin liberation by TMAO was maximum around $\mathrm{pH} \mathrm{4,} \mathrm{at} \mathrm{which} \mathrm{there} \mathrm{was} \mathrm{also}$ marked decomposition of TMAO. Around that $\mathrm{pH}$, the amount of tin liberated was proportional to that of TMAO added. Tin liberation by TMAO increased both at higher temperatures and with the lapse of time at $37^{\circ} \mathrm{C}$. Generally, the amount of tin liberated almost paralleled that of TMAO decomposed. Both tin liberation and TMAO decomposition were to a certain extent depressed by phytic acid and inositol. From these results, it was concluded that tin liberation from tinplate cans is caused by TMAO.
\end{abstract}

In canned foods, much attention is paid to the internal corrosion of food can, since this usually results in the metallic contamination of the contents. Though there have been published many reports on the corrosion processes of metals, ${ }^{1-3}$ the mechanism involved in the internal detinning of food can remains for the most part to be elucidated.

It is well known by experience that the internal tin layer of food can is rapidly attacked by trimethylamine oxide (TMAO) at high levels. ${ }^{4)}$ The present study was carried out to obtain the fundamental information of the liberation process of tin in tinplate can, using a model system containing TMAO.

\section{Experimental}

Buffered TMAO solutions In the distilled water previously boiled to minimize the dissolved oxygen, was dissolved TMAO at 5-50 mM. After addition of citric acid to a final concentration of $1 / 10 \mathrm{M}$, the solutions were adjusted with $1 / 5 \mathrm{M}$ phosphate to various $\mathrm{pH}$ values between 2.8 and 8.0 .

Canning procedures The buffered TMAO solutions thus prepared were canned in plain tinplate cans ( $74.1 \mathrm{~mm}$ in diameter; $59.0 \mathrm{~mm}$ in height) by over-filling to avoid the headspace. After heating in a boiling water bath for 60 min unless otherwise stated, the cans were cooled immediately in cold water and stored at $37^{\circ} \mathrm{C}$. At suitable intervals the TMAO solution was taken from each can and analyzed for the amounts of tin liberated and the remaining TMAO.

Analytical methods Tin was determined polarographically employing $1 \mathrm{~N} \mathrm{HCl}-$ $1 \mathrm{~N} \mathrm{NH}{ }_{4} \mathrm{Cl}$ as the supporting electrolyte. TMAO was determined according to DYER et

\footnotetext{
* Tokyo University of Fisheries, Konan, Minato-ku, Tokyo (田口 武：東京水産大学)
} 
$a .^{3)}$ The remaining amount of TMAO was expressed as percent of the initial amount of TMAO.

\section{Results and Discussion}

Effect of pH on tin liberation The corrosive action of a detinner in electrolytic solutions is greatly dependent on the $\mathrm{pH}$ of media. The cans containing $10 \mathrm{mM}$ TMAO at seven different $\mathrm{pH}$ values were heated at $100^{\circ} \mathrm{C}$ for $60 \mathrm{~min}$ and stored at $37^{\circ} \mathrm{C}$ for 2 days. As shown in Fig. 1, the tin liberated was highest around $\mathrm{pH} 4$ in the range of 2.8-8.0. The amount of remaining TMAO was minimum approximately at this $\mathrm{pH}$. In the absence of TMAO, the tin liberation was much smaller over this $\mathrm{pH}$ range.

Effect of TMAO concentration on tin liberation The effect of TMAO concentration on the tin liberation was examined at $\mathrm{pH} 4.0$. As given in Fig. 2, the tin liberation was almost proportional to the amount of TMAO added. In addition, a slight increase of $\mathrm{pH}$ of the buffered TMAO solution by heating was observed. This $\mathrm{pH}$ increase is probably due to the formation of amines and/or ammonia from TMAO.

Effect of heating on tin liberation A $10 \mathrm{~mm}$ TMAO solution ( $\mathrm{pH} \mathrm{3.8)} \mathrm{was} \mathrm{canned}$ and heated at $100^{\circ} \mathrm{C}$, and the time course of tin liberation was examined. As shown in Fig. 3, the amount of tin liberated was increased hyperbolically with the time of heating.

The effect of temperature on the tin liberation was also examined. In the preliminary experiments, a significant temperature effect on the tin liberation was found in the presence of large amounts of TMAO. Hence, the cans packed with the solution containing $50 \mathrm{~mm}$ TMAO at $\mathrm{pH} 3.7$ were incubated at various temperatures for $60 \mathrm{~min}$ and analyzed. As

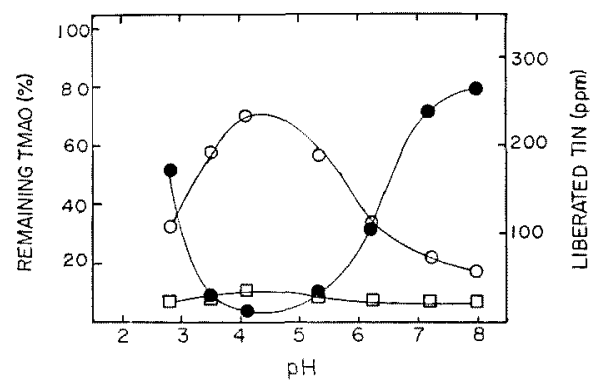

Fig. 1. Effect of $\mathrm{pH}$ on the liberation of tin by TMAO. The cans containing $10 \mathrm{~mm}$ TMAO were heaed at $100^{\circ} \mathrm{C}$ for $60 \mathrm{~min}$. $O$ : Liberated tin in the presence of TMAO

$\square$ : Liberated tin in the absence of TMAO

- Remaining TMAO

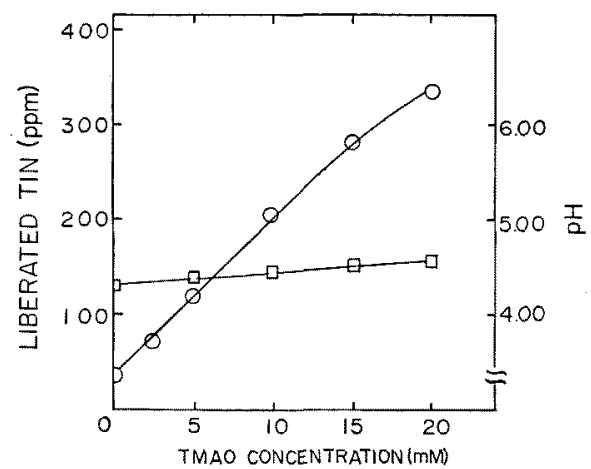

Fig. 2. Effect of TMAO on the liberation of tin. The cans containing TMAO and $0.0615 \mathrm{M}$ citric acid- $0.0771 \mathrm{M}$ phosphate buffer $\left(\mathrm{pH} 4.0\right.$ ) were heated at $100^{\circ} \mathrm{C}$ for $60 \mathrm{~min}$.

0 : Liberated tin

$\square$ : $\mathrm{pH}$ after heating 


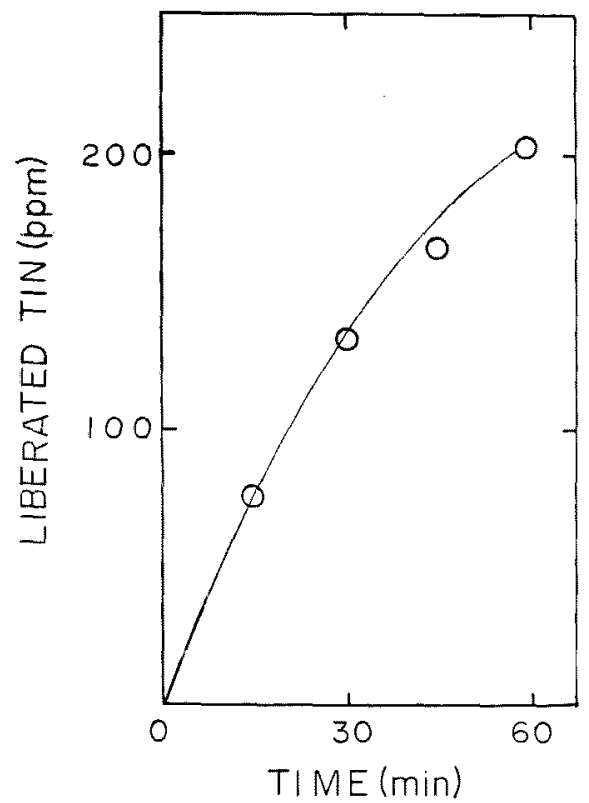

Fig. 3. Time course of tin liberation by TMAO. The cans containing $10 \mathrm{~mm}$ TMAO and the same buffer as in Fig. 2 were heated at $100^{\circ} \mathrm{C}$.

can be seen in Fig. 4, the rate of tin liberation sharply increased near $50^{\circ} \mathrm{C}$ under these conditions. These results suggest that the tin liberation proceeds according to ARRHENIUS formula below $50^{\circ} \mathrm{C}$, beyond which the liberation is to some degree depressed by a weak ionization of oxygen. ${ }^{6)}$

Tin liberation during storage The cans containing the buffered $10 \mathrm{mM}$ TMAO solu-

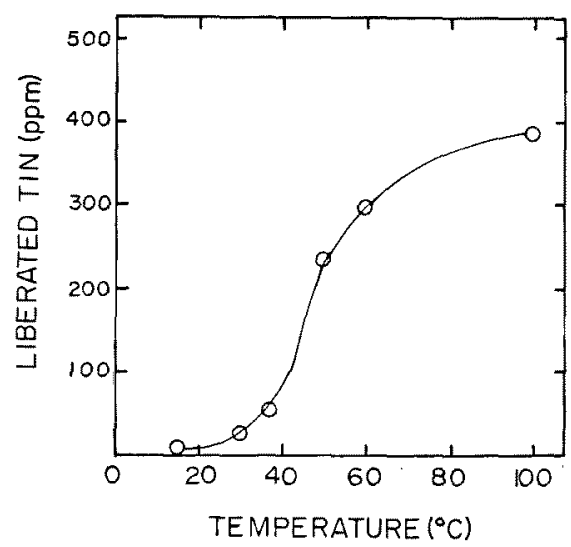

Fig. 4. Effect of temperature on the tin liberation by TMAO.

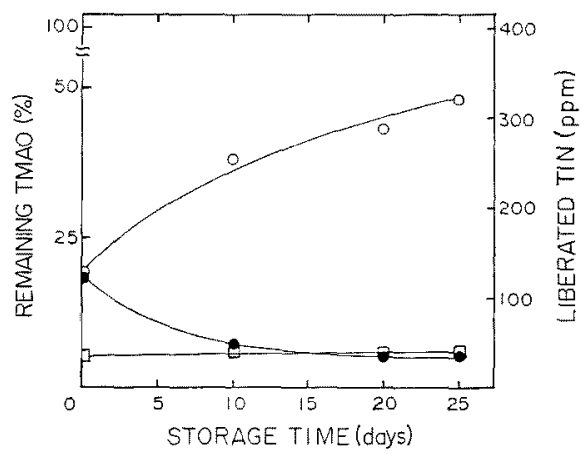

Fig. 5. Tin liberation by TMAO during storage at $37^{\circ} \mathrm{C}$. The cans were stored at $37^{\circ} \mathrm{C}$ after heating at $100^{\circ} \mathrm{C}$.

0 : Liberated tin in the presence of TMAO

$\square$ : Liberated tin in the absence of TMAO

- Remaining TMAO tion at $\mathrm{pH} 4.0$ were heated at $100^{\circ} \mathrm{C}$ for $30 \mathrm{~min}$. The cans containing the buffer solution alone were also prepared as the control. These cans were kept for 25 days at $37^{\circ} \mathrm{C}$. As shown in Fig. 5, the amount of tin liberated increased rather hyperbolically with the storage time, while the amount of TMAO decreased almost correspondingly. The concentration of tin liberated in the control cans remained unchanged throughout the period of storage.

Depression of tin liberation Some attempts were made to depress the tin liberation caused by TMAO. Since the corrosion of metals is depressed by a organic colloidal solution, ${ }^{7)}$ phytic acid and inositol were tested here. Phytic acid and inositol were added at 
Table 1. Depression by phytic acid and inositol of the tin liberation by TMAO. The cans containing $0.5 \mathrm{~mm}$ phytic acid and $2 \mathrm{~mm}$ inositol to $5 \mathrm{~mm}$ TMAO-20 mM citric acid were stored at $37^{\circ} \mathrm{C}$ for 3 days after heating at $100^{\circ} \mathrm{C}$ for $15 \mathrm{~min}$.

\begin{tabular}{lccc}
\hline & $\begin{array}{c}\text { Liberated } \\
\text { tin } \\
(\mathrm{ppm})\end{array}$ & $\begin{array}{c}\text { Depression } \\
(\%)\end{array}$ & $\begin{array}{c}\text { Remaining } \\
\text { TMAO } \\
(\%)\end{array}$ \\
\hline Control & 77.3 & & 10.0 \\
Phytic acid $(0.5 \mathrm{mM})$ & 52.0 & 32.7 & 39.8 \\
Inositol $(2 \mathrm{~mm})$ & 62.8 & 18.7 & 23.5 \\
Phytic acid $(0.5 \mathrm{~mm})+$ inositol $(2 \mathrm{~mm})$ & 44.5 & 42.4 & 44.0 \\
\hline
\end{tabular}

the final concentrations of 0.5 and $2 \mathrm{mM}$, respectively, to the buffered TMAO solution, and heated at $100^{\circ} \mathrm{C}$ for $15 \mathrm{~min}$. After storage at $37^{\circ} \mathrm{C}$ for 3 days, the amount of tin liberated was assayed. As seen in Table 1, the tin liberation as well as the decomposition of TMAO were fairly effectively depressed by phytic acid and inositol, especially by the former.

From these results, it is reasonably concluded that the tin liberation from a tinplate can is caused by TMAO. Further studies on the depression of tin liberation by these agents are now in progress.

\section{References}

1) R. P. Farrow, N. T. Lao, and E. S. KIM: J. Food Sci, 35, 818-822 (1970).

2) K. SuzukI: The Canners $J$. (in Japanese), 50, 104-108 (1971).

3) L. D. Perrigo: Food Technol., 28, (12) 54-58 (1974).

4) S. Otsuka, T. Tommaga, H. Osada, and I. Kato: The Canners J. (in Japanese), 47, 163-169 (1968).

5) W. J. Dyer, F. E. Dyer, and J. M. Snow: J. Fish. Res. Bd. Can., 8, 309-313 (1954).

6) G. OKamoto and K. Inoue: "Fushoku to Bōshoku" (ed. by The Chemical Society of Japan), Dainihontosho Co., Tokyo, 1971, pp. 126-127.

7) G. OKamoto and K. INove: ibid., 1971, pp. 77-78. 